\title{
B.I CHECKING SEBAGAI ALAT BUKTI DALAM PEMBUKTIAN SEDERHANA PERKARA KEPAILITAN
}

\author{
Christopher Panal Lumban Gaol \\ Fakultas Hukum Universitas Katolik Santo Thomas, Medan, Indonesia \\ Email: C.thoperlg@gmail.com
}

\begin{abstract}
ABSTRAK
Dunia bisnis membutuhkan kepastian dalam melakukan kegiatan ekonomi yang menjadi tulang punggung dari perekonomian, dan pebisnis membutuhkan kepastian hukum agar tidak terjadi multitafsir dalam melakukan kegiatan bisnis tersebut. Perbankan adalah kegiatan bisnis dalam bidang jasa keuangan yang sangat membutuhkan hukum untuk menjalankan bisnisnya, jika tidak ada hukum maka penghimpunan dana masyarakat akan kacau. Kegiatan-kegiatan ini membutuhkan pengawasan dan juga membutuhkan kewenangan agar dapat berjalan dengan tertib dan tenang. Ketidakpastian hukum akan merugikan seluruh pihak, baik itu negara, rakyat dan juga pebisnis. Jika ingin melihat lebih jauh pastinya investasi tidak akan berjalan dengan baik, yang artinya uang dari luar negeri tidak akan masuk ke Indonesia. Penguatan dalam hukum dalam bidang bisnis merupakan keharusan dan juga banyak menjadi perhatian dari negara maju. Alat bukti merupakan sarana yang dapat digunakan untuk memperkuat dalil dalam hukum acara. Hukum acara dalam perkara kepailitan mempunyai perbedaan, yaitu harus dapat dibuktikan secara sederhana. Pendekatan normatif yuridis dengan deskriptif analitis merupakan metode penelitian yang digunakan dalam tulisan ini. Pembuktian dengan cara sederhana mengenai adanya dua atau lebih kreditor dapat dilakukan melalui B.I Checking. Dikarenakan data tersebut dikelola oleh bank sentral di Indonesia, sehingga keabsahan data tersebut dapat dijamin, serta data tersebut dapat diakses melalui internet, sehingga dapat diambil dan ditampilkan dimuka pengadilan secara sederhana.
\end{abstract}

Kata kunci: kepailitan, pembuktian sederhana, B.I Checking.

\section{ABSTRACT}

The business world needs certainty in carrying out economic activities that are the backbone of the economy, and business people need legal certainty so that there will be no multiple interpretations in carrying out these business activities. Banking is a business activity in the field of financial services that really needs the law to run its business. If there is no law, public fund raising will be chaotic. These activities require supervision and also require authority so that they can run in an orderly and calm manner. Legal uncertainty will be detrimental to all parties, be it the state, the people and business people. If you want to see further, surely the investment will not go well, which means that money from abroad will not enter Indonesia. Strengthening in law in the field of business is a must and also a lot of attention from developed countries. Evidence is a tool that can be used to strengthen the argument in the procedural law. The procedural law in a bankruptcy case has a difference, it must be proven simply. The normative juridical approach with

B.I Checking Sebagai Alat Bukti Dalam Pembuktian Sederhana Perkara Kepailitan Oleh : Christopher Panal Lumban Gaol 
analytical descriptive is the research method used in this paper. Simple proof of the existence of two or more creditors can be done through B.I Checking. Because the data is managed by the central bank in Indonesia, so the validity of the data can be guaranteed, and the data can be accessed via the internet, so that it can be easily taken and displayed in court.

Key words: bankruptcy, simple verification, B.I Checking.

\section{A. PENDAHULUAN}

Utang adalah kewajiban yang dinyatakan atau dapat dinyatakan dalam jumlah uang baik dalam mata uang Indonesia maupun mata uang asing, baik secara langsung maupun yang akan timbul di kemudian hari atau kontinjen, yang timbul karena perjanjian atau undang-undang dan yang wajib dipenuhi oleh Debitor dan bila tidak dipenuhi memberi hak kepada Kreditor untuk mendapat pemenuhannya dari harta kekayaan Debitor. ${ }^{1}$ Kepailitan adalah sita umum atas semua kekayaan Debitor pailit yang pengurusan dan pemberesannya dilakukan oleh kurator di bawah pengawasan Hakim Pengawas sebagaimana diatur dalam Undang-Undang. ${ }^{2}$

Pembuktian dalam kepailitan mempunyai perbedaan dengan perkara perdata lainnya, yaitu harus dapat dibuktikan secara sederhana. Sesuai yang tertera dalam Undang-Undang No. 34 tahun 2004 mengenai Kepailitan dan Penundaan Kewajiban Pembayaran Utang yang selanjutnya disebut sebagai "UUKPKPU" dalam pengajuan perkara kepailitan di Pengadilan Niaga oleh kreditur, dalam Pasal 2 angka 1 jo. Pasal 8 angka 4 UUKPKPU tentang persyaratan pengajuan kepailitan adalah Ada dua atau lebih kreditor, Ada utang yang telah jatuh waktu dan dapat ditagih dan Kedua hal tersebut (adanya dua atau lebih kreditor dan adanya utang yang telah jatuh tempo dan dapat ditagih) dapat dibuktikan secara sederhana. ${ }^{3}$

Ketentuan ketentuan Pasal 8 ayat (4) UUKPKPU telah memenuhi dan sesuai dengan asas kepastian hukum (memberi kepastian hukum), sesuai dengan asas atau teori keadilan (memberikan dan menciptakan keadilan) dan sesuai dengan asas kemanfaatan atau teori Utilitarianisme (memberikan banyak manfaat kepada

\footnotetext{
${ }^{1}$ Pasal 1 ayat 6 Undang-Undang Nomor 34 Tahun 2004 tentang Kepailitan dan Penundaan Kewajiban Pembayaran Utang.

${ }^{2}$ Ibid., Pasal 1 angka 1.

${ }^{3}$ Ibid., Pasal 2 angka 1 jo. Pasal 8 angka 4.
}

B.I Checking Sebagai Alat Bukti Dalam Pembuktian Sederhana Perkara Kepailitan Oleh : Christopher Panal Lumban Gaol 
kepentingan pihak-pihak dan kepentingan usaha ekonomi), maka dapat dikatakan bahwa ketentuan Pasal 8 ayat (4) UUKPKPU merupakan hukum yang ideal. ${ }^{4}$

Pembuktian mengenai adanya dua atau lebih kreditor dalam beberapa kasus dilakukan secara sederhana melalui BI Checking, menggunakan Informasi Debitur Individual Historis (IDI Historis) dan menggunakan Sistem Informasi Debitor yang dikelola oleh Bank Indonesia. Dalam praktek terjadi kebingungan dikarenakan beberapa kasus-kasus yang terjadi, melakukan pembuktian menggunakan IDI Historis dari BI Checking ditolak oleh pengadilan. Kesulitan melakukan pembuktian adanya dua Kreditor atau lebih tersebut sebab daftar Kreditor yang dimiliki oleh Debitor tersebut, berada didalam kuasa Debitor. Adanya ketidaksepahaman mengenai posisi dari Debitor tersebut juga menjadi permasalahan karena walaupun Debitor memiliki banyak Kreditor tetapi tidak semua Kreditor sepaham, Kreditor lain masih beranggapan kalau Debitor tersebut masih dapat membayarkan utangnya. Tidak jelasnya pengertian bagaimana tentang cara membuktikan secara sederhana dapat dilihat melalui kasus di Pengadilan Niaga.

Terdapat putusan yang berbeda dari putusan Pengadilan Niaga terhadap fakta pembuktian menggunakan BI Checking. Berdasarkan Putusan dalam perkara No:1/PKPU/2012/PN.NIAGA.SMG ${ }^{5}$ diputuskan bahwa BI Checking diakui sebagai alat bukti yang dapat membuktikan secara sederhana tentang adanya dua atau lebih Kreditor, berdasarkan UU ITE. Putusan tersebut dikuatkan oleh Mahkamah Agung No.748 K/PDT.SUS/2012. ${ }^{6}$ Sedangkan terhadap Putusan dalam perkara No.26/Pdt.Sus/Pailit/2014/ PN.NIAGA.JKT.PST, ${ }^{7}$ Hakim memberikan keputusan berbeda untuk memutus apakah BI Checking dapat digunakan atau tidak. Berdasarkan Yurisprudensi Mahkamah Agung RI No.443 K/Pdt.Sus/2009 ${ }^{8}$ memberikan Putusan dalam perkara No.26/Pdt.Sus/Pailit/2014/PN.NIAGA.JKT.PST adalah BI Checking tidak dapat diterima sebagai alat bukti. Putusan ini diikuti Putusan-Putusan dalam perkara

\footnotetext{
4 Indah Wijayanti, 2006, "Penerapan Penafsiran Pembuktian Sederhana Dalam Perkara Kepailitan”, (Jurnal Hukum Universitas Brawijaya, Malang), hlm. 59

${ }^{5}$ Putusan dengan Perkara No.1/PKPU/2012/PN.NIAGA.SMG.

${ }^{6}$ Putusan Mahkamah Agung No.748 K/PDT.SUS/2012.

${ }^{7}$ Putusan dengan Perkara No.24//PDT.SUS/2014/PN.NIAGA.JKT.PST

${ }^{8}$ Putusan Mahkamah Agung RI No.443 K/Pdt.Sus/2009.
}

B.I Checking Sebagai Alat Bukti Dalam Pembuktian Sederhana Perkara Kepailitan Oleh : Christopher Panal Lumban Gaol 
No.92/PDT.SUS/PKPU/2015/ PN.NIAGA.JKT.PST, Putusan dalam perkara No.93/PDT.SUS/PKPU/2015/ PN.NIAGA.JKT.PST, serta putusan dalam Perkara No.86/PDT.SUS-PKPU/2016/PN.Niaga.JKT.PST.

\section{B. RUMUSAN MASALAH}

Berdasarkan permasalahan di atas, permasalahan yang diangkat adalah Apakah BI Checking dapat dibuktikan sebagai alat dalam pembuktian sederhana?

\section{METODE PENELITIAN}

Tulisan ini dibuat berdasarkan hasil penelitian yuridis normatif dengan menggunakan metode deskriptif analitis. Penelitian ditujukan untuk menganalisis bahan-bahan hukum yang mengacu kepada norma-norma hukum yang terdapat dalam peraturan perundang-undangan dan putusan pengadilan. ${ }^{9}$ Penelitian ini dilakukan melalui penelitian kepustakaan (library research) atau dokumen peraturan perundang-undangan seperti Kitab Undang-undang Hukum Perdata, Undang-Undang Nomor 34 Tahun 2004 Tentang Kepailitan dan Penundaan Kewajiban Pembayaran Utang, buku, jurnal hukum, dan berbagai putusan pengadilan yang berkaitan dengan Kepailitan dan Penundaan Kewajiban Pembayaran Utang pada pembuktian yang menggunakan BI Checking.

\section{PEMBAHASAN}

\section{BI Checkhing}

Bank Indonesia mempunyai tujuan untuk mencapai dan memelihara kestabilan nilai rupiah. ${ }^{10}$ Sistem Informasi Debitor merupakan suatu sistem yang dipergunakan untuk menghimpun dan menyimpan data fasilitas penyediaan dana/pembiayaan yang disampaikan oleh seluruh anggota Biro Informasi Kredit secara rutin setiap bulan kepada Bank Indonesia. Data tersebut kemudian diolah untuk menghasilkan output berupa IDI Historis. Isi dari IDI historis ini mencakup seluruh penyediaan dana atau pembiayaan dengan kondisi lancar atau bermasalah, serta berisi tentang informasi mengenai sejarah pembayaran kredit "debitor" dalam

9 Ridwan Khairandy, 2011, “Landasan Filosofis Kekuatan Mengikatnya Kontrak”, Jurnal Hukum, No. Edisi khusus vol 18, Depok, hlm.39.

10 Bank Indonesia, "Fungsi dan Tujuan Bank Indonesia", http://www.bi.go.id/id/tentangbi/fungsi-bi/tujuan/Contents/Default.aspx, diakses pada tanggal 19/04/2017 pukul 00:44.

B.I Checking Sebagai Alat Bukti Dalam Pembuktian Sederhana Perkara Kepailitan Oleh : Christopher Panal Lumban Gaol 
kurun waktu 24 bulan terakhir. ${ }^{11}$ Bank yang menjadi Kreditor Preferen menggunakan IDI Historis yang merupakan bagian dari BI Checking sebagai alat bukti adanya dua atau tiga Kreditor yang dimiliki oleh Debitor.

\section{Permohonan Kepailitan}

Kepailitan adalah sita umum atas semua kekayaan debitor pailit yang pengurusan dan pemberesannya dilakukan oleh kurator di bawah pengawasan hakim pengawas. Kepailitan merupakan suatu sitaan dan eksekusi atas seluruh kekayaan debitor dengan tujuan membagikan harta tersebut untuk membayar utangutang debitor kepada para kreditornya secara pari passu atau berimbang, kecuali ada kreditor yang memiliki hak istimewa untuk didahulukan. ${ }^{12}$

Permohonan kepailitan diajukan ke Pengadilan Niaga melalui panitera Pengadilan Niaga tersebut, yang dapat mengajukan permohonan kepailitan adalah Debitor, Kreditor, Kejaksaan, dalam hal untuk kepentingan umum, Bank Indonesia, dalam hal debitornya merupakan bank, Badan Pengawas Pasar Modal (Bapepam), dalam hal debitornya perusahaan efek, bursa efek, atau lembaga kliring dan penjaminan; dan Menteri Keuangan, dalam hal ini debitornya adalah perusahaan asuransi, perusahaan reasuransi, dana pensiun, atau Badan Usaha Milik Negara (BUMN) yang berkecimpung di bidang kepentingan publik. ${ }^{13}$ Permohonan kepailitan tersebut wajib dilakukan melalui advokat kecuali jika pemohonnya adalah kejaksaan, Bank Indonesia, Bapepam, atau Menteri Keuangan. ${ }^{14}$

\section{Pembuktian}

Membuktikan adalah meyakinkan hakim tentang kebenaran dalil-dalil yang dikemukakan dalam suatu persengketaan. Pada dasarnya, esensi pembuktian adalah untuk menentukan hubungan hukum yang sebenarnya antara para pihak yang berperkara, meliputi kejadian atau peristiwa serta suatu hak yang didalilkan oleh para pihak, dan menjadi objek perselisihan. Pembuktian Sederhana adalah pembuktian mengenai Eksistensi dari suatu utang debitor yang dimohonkan

\footnotetext{
${ }^{11}$ Bank Indonesia, "IDI Historis”, http://www.bi.go.id/en/perbankan/biro-informasi-kredit/idihistoris, diakses pada tanggal 10/11/2016 pukul 21:21 WIB.

12 Bagus Irawan, 2007, “Aspek-aspek Hukum Kepailitan, Perusahaan, dan Asuransi”, (PT Alumni, Bandung), hlm. 9.

13 M. Hadi Shubhan, 2014, "Hukum Kepailitan Prinsip, Norma, dan Praktik di Peradilan", (Kencana Prenada Media Group, Jakarta), hlm. 119.

14 Ibid.
}

B.I Checking Sebagai Alat Bukti Dalam Pembuktian Sederhana Perkara Kepailitan Oleh : Christopher Panal Lumban Gaol 
kepailitan, yang telah jatuh tempo dan Eksistensi dari dua atau lebih kreditor dari debitor yang dimohonkan kepailitan. Dalam Perkara Kepailitan harus menerapkan pembuktian sederhana, dimana pembuktian ini merupakan penerapan dari Pasal 8 ayat (4) Undang-Undang Kepailitan yakni Bahwa Permohonan pernyataan pailit harus dikabulkan apabila terdapat fakta atau keadaan yang terbukti secara sederhana. Maksud dari fakta atau keadaan yang terbukti secara sederhana adalah adanya fakta dua atau lebih Kreditor dan fakta utang yang telah jatuh waktu dan tidak dibayar. ${ }^{15}$

Alat-alat bukti baru kini muncul dalam lalu lintas keperdataan dunia modern, sejauh mana daya pembuktiannya dalam hukum pembuktian perdata yang modern dewasa ini. Alat alat bukti yang baru muncul itu, misalnya Pembicaraan telepon, Testing darah, Hasil komputer, Fotocopy, Rekaman kaset, Hasil fotografi. ${ }^{16}$

Tercantum juga di Pasal 5 UU Nomor 11 Tahun 2008 tentang Informasi dan Transaksi Elektronik (UU ITE) mengatur sebagai berikut (1) Informasi Elektronik dan/atau Dokumen Elektronik dan/atau hasil cetaknya merupakan alat bukti hukum yang sah; (2) Informasi Elektronik dan/atau Dokumen Elektronik dan/atau hasil cetaknya dimaksud pada ayat (1) merupakan perluasan dari alat bukti yang sah sesuai dengan Hukum Acara yang berlaku di Indonesia.

\section{Pembuktian sederhana dalam Kepailitan}

Menurut Paulus E. Lotulung, pembuktian sederhana dalam perkara kepailitan dapat dilakukan apabila pihak Termohon Pailit atau debitor tidak mengajukan tangkisan berdasarkan prinsip exceptio non adimpleti contractus, yaitu tangkisan yang menyatakan bahwa kreditor sendiri yang lebih dahulu tidak berprestasi. Prinsip exceptio non adimpleti contractus terdapat dalam perjanjian timbal balik, yang menyebabkan eksistensi utang masih diperdebatkan, sehingga pembuktiannya tidak dapat dilakukan secara sederhana dan cepat. ${ }^{17}$

Menurut pendapat ahli, pembuktian sederhana dapat dilakukan apabila pihak termohon atau debitor pailit tidak mengajukan exeptio non adimpleti contractus,

\footnotetext{
15 Aria Syudi et al., 2003, “Analisis Kepailitan Indonesia (Kepailitan di Negeri Pailit)”, (PSHK, Jakarta), hlm. 147.

16 Ibid., p. 78.

17 Paulus E. Lotulung, 2004, “Pengertian Pembuktian Sederhana dalam Perkara Kepailitan”, (Majalah Ombudsman, No. 54, Jakarta), p. 10.
}

B.I Checking Sebagai Alat Bukti Dalam Pembuktian Sederhana Perkara Kepailitan Oleh : Christopher Panal Lumban Gaol 
yaitu eksepsi yang menyatakan bahwa kreditor sendiri yang lebih dahulu tidak berprestasi. Exeptio non adimpleti contractus ini terdapat dalam perjanjian timbalbalik, yang menyebabkan eksistensi utang masih diperdebatkan, sehingga pembuktiannya tidak dapat dilakukan secara sederhana dan cepat. ${ }^{18}$

Pembuktian sederhana ini juga berkaitan dengan singkatnya jangka waktu putusan pernyataan pailit yang harus ditetapkan dalam jangka waktu paling lambat 30 (tiga puluh) hari terhitung sejak tanggal permohonan pernyataan pailit didaftarkan. ${ }^{19}$

Bahwa pemohon harus dapat membuktikan bahwa adanya dua atau lebih kreditor yang telah jatuh tempo dan dapat ditagih dan harus dapat dibuktikan secara sederhana, penggunaan pembuktian sederhana dalam hal ini menjadi sangat tidak jelas dalam dewasa ini. Bahwa debitor itu sendiri yang mengetahui kepada kreditor siapa saja dia mengutang. Menggunakan BI Checking kreditor tersebut tidak perlu menggunakan keputusan pengadilan untuk mencari berkas ataupun data tentang kepada siapa saja debitor tersebut mengutang.

Bahwa dalam hal ini penulis menitik beratkan dalam penggunaan alat bukti tersebut adalah sebuah hal yang sederhana dilihat dari mana alat bukti tersebut dapat diambil dan dipergunakan. Bahwa alat bukti melalui BI Checking dapat diakses melalui online dan dapat langsung di cetak. Barang bukti tersebut juga dapat diverifikasi melalui Bank Indonesia, sehingga dapat ditentukan apakah hal tersebut data yang dikeluarkan Bank Indonesia atau tidak. Melihat dari UUKPKPU meminta bahwa adanya dua atau lebih kreditor harus dapat dibuktikan secara sederhana.

Berdasarkan teori kepastian hukum yang dikemukakan oleh Peter Mahmud Marzuki kepastian hukum adalah kepastian berupa pasal-pasal dalam undang-undang tetapi juga dalam penerapannya. ${ }^{20}$ Satjpto Rahardjo menyatakan bahwa penafsiran hukum

18 Paulus E. Lotulung, 2010, "Pengertian Pembuktian Sederhana dalam Kepailitan" dalam Dalam Perkara Kepailitan”, (Mimbar Hukum, Jurnal Ilmiah Mahasiswa Universitas Gajah Mada, Yogyakarta), hlm. 486.

19 Nina Noviana, 2006, "Perubahan Pokok Dalam Peraturan Kepailitan Menurut UndangUndang Nomor 37 Tahun 2004 Tentang Kepailitan Dan Penundaan Kewajiban Pembayaran Utang”, (Jurnal Hukum dan Pembangunan, Jakarta), hlm. 135.

20 Peter Mahmud Marzuki, 2013, "Pengantar Ilmu Hukum”, (Kencana, Jakarta), hlm. 137.

B.I Checking Sebagai Alat Bukti Dalam Pembuktian Sederhana Perkara Kepailitan Oleh : Christopher Panal Lumban Gaol 
dilihat dari tujuannya terbagi atas penafsiran pasif (penafsiran makna hukum aslinya atau sebenarnya) dan penafsiran hukum aktif atau responsive (penafsiran hukum untuk memenuhi kebutuhan penegakan hukum).Penafsiran hukum dapat dilakukan apabila hukumnya kurang jelas atau tidak jelas atau bertentangan atau tumpang tindih dengan aturan hukum lainnya. Apabila aturan hukumnya sudah jelas, atau kata-kata yang tercantum dalam suatu ketentuan perundang- undangan sudah jelas dan tegas, maka hal itu mengakhiri pencarian maksud atau penafsiran hukumnya, yang disebut maxsim expressum facit cassare tacitum, yaitu, bahwa kata-kata yang dicantumkan secara tegas mengakhiri pencarian mengenai maksud dari suatu perundang-undangan. ${ }^{21}$

Penulis dalam hal ini membawa lima (5) kasus yang berhubungan dengan keputusan Pengadilan Niaga yang berhubungan dengan pembuktian sederhana mengenai adanya dua atau lebih kreditor yang dimana terdapat tiga (3) kasus yang ditolak dan dua (2) yang diterima yaitu Perkara No:70/PAILIT/2010/PN.NIAGA.JKT.PST, Perkara No: 1/PKPU/2012/PN.NIAGASMG, Perkara No: 92/PDT.SUS/PKPU/2015/PN.NIAGA.JKT.PST, Perkara No :93/PDT.SUS/PKPU/2015/PN.NIAGA.JKT.PST, Perkara No:86/PDT.SUSPKPU/2016/PN.Niaga.JKT.PST.

Berdasarkan lima (5) putusan diatas terdapat ketidak jelasan dalam hal pembuktian menggunakan BI Checking sebagai alat bukti. Bahwa berdasarkan Putusan dengan perkara No. Perkara No:70/PAILIT/2010/PN.NIAGA.JKT.PST. dan Putusan dengan perkara No: 1/PKPU/2012/PN.NIAGA.SMG memutuskan bahwa BI Checking diakui sebagai alat bukti yang dapat membuktikan secara sederhana tentang adanya dua atau lebih Kreditor, berdasarkan UU ITE. Sehingga Permohonan diterima.

Berbanding terbalik untuk Putusan dengan perkara No.92/PDT.SUS/PKPU/2015/PN.NIAGA.JKT.PST, putusan dengan perkara No:93/PDT.SUS/PKPU/2015/PN.NIAGA.JKT.PST, serta putusan dengan Perkara No:86/PDT.SUS-PKPU/2016/PN.Niaga.JKT.PST. Memutuskan bahwa BI

${ }^{21}$ Satjipto Rahardjo,2014, “Ilmu Hukum”, (Citra Aditya Bakti, Bandung), hlm. 97-98.

B.I Checking Sebagai Alat Bukti Dalam Pembuktian Sederhana Perkara Kepailitan Oleh : Christopher Panal Lumban Gaol 
Checking bukanlah sebuah alat bukti yang cukup kuat dan juga masih berubah-ubah serta harus dikuatkan dengan adanya Kreditor lainnya untuk dapat dijadikan alat bukti.

Dunia Perekonomian mengalami kepastian hukum mengenai mana yang akan digunakan. Bank-bank yang menjadi Kreditor tidak akan menjadi nyaman jika ada Debitor yang tidak dapat membayarkan utangnya dan harus menempuh jalur Kepalaitan. Tentang bagaimana dapat menempuh jalur tersebut dengan menentukan bagaimana menentukan tentang adanya dua atau lebih kreditor secara sederhana jika Debitor dan Kreditor lainnya tidak dapat berkerjasama. Hal ini dapat berakibat pada kelangsungan usaha daripada Kreditor itu sendiri, dikarenakan tidak dapat ditagihnya utang tersebut dapat mengakibatkan kerusakan sistem keuangan mereka. Hal ini juga dapat berdampak kepada masyarakat yang memiliki tabungan di bank tersebut. Dimana bank merupakan lembaga penghimpun dana dari masyarakat luas.

\section{E. KESIMPULAN}

Pembuktian sederhana berdasarkan pasal 8 ayat (4) cukup jelas untuk membuktian adanya dua kreditor atau setidaknya satu utang yang telah jatuh tempo, penggunaan asas-asas kepastian hukum, keadilan dan kemanfaatan telah dipergunakan dimana hal itu adalah tujuan hukum tersebut dibuat.

Penggunaan BI Checking sebagai alat bukti seharusnya dapat diterima dikarenakan tidak bertentangan dengan UU ITE dan hukum pembuktian dalam Hukum Acara Perdata. Berdasarkan Pasal 2 ayat (1), bahwa permohonan pailit hanya untuk memeriksa dan menerapkan Undang-Undang No. 37 Tahun 2004 saja, pemeriksaan apakah sudah memenuhi syarat untuk diterima permohonan ataukah tidak, apakah hukumnya sudah diterapkan atau tidak. Jika permohonan tersebut dapat dibuktikan secara sederhana melalui BI Checking dan tidak bertentangan dengan Undang-Undang yang lain maka tidak ada alasan untuk tidak menjatuhkan putusan pailit.

\section{DAFTAR PUSTAKA}

Ali, Achmad \& Heryani Wiwie, 2013, Asas-asas Hukum Pembuktian Perdata, Kencana, Prenadamedia Group, Jakarta.

Asikin, Zainal, 2013, Hukum Kepailitan dan Penundaan Pembayaran di Indonesia, Pustaka Reka Cipta, Bandung. 
Hartanto, J. Andy, 2015, Hukum Jaminan Dan Kepailitan, Hak Kreditor Separatis dalam Pembagian Hasil Penjualan Benda Jaminan Debitor Pailit, Laksbang Justitia Surabaya, Surabaya.

Irawan, Bagus, 2007, Aspek-aspek Hukum Kepailitan, Perusahaan, dan Asuransi, PT Alumni, Bandung.

Kamus Besar Bahasa Indonesia

Lotulung, Paulus E., 2004, Pengertian Pembuktian Sederhana dalam Perkara Kepailitan, Majalah Ombudsman, Jakarta.

Manik, Edward, 2012, Cara Mudah Memahami Proses Kepailitan dan Penundaan Kewajiban Pembayaran Utang (Dilengkapi dengan Studi Kasus Kepailitan), Mandar Maju, Bandung.

Marzuki, Peter Mahmud, 2013, Pengantar Ilmu Hukum, Kencana, Jakarta.

Mulyadi, Lilik, 2013, Perkara Kepailitan Dan Penundaan Kewajiban Pembayaran Utang (PKPU) Teori Dan Praktik, Dilengkapi PutusanPutusan Pengadilan Niaga, P.T. Alumni, Bandung.

Rahardjo, Satjipto, 2014, Ilmu Hukum, Citra Aditya Bakti, Bandung.

Sastrawidjaja, Man S, 2014, Hukum Kepailitan dan Penundaan Kewajiban Pembayaran utang, P.T. ALUMNI, Bandung.

Shubhan, M. Hadi, 2014, Hukum Kepailitan Prinsip, Norma, dan Praktik di Peradilan, Kencana Prenada Media Group, Jakarta.

Situmorang, Victor, et al., 1994, Pengantar Hukum Kepailitan di Indonesia, Rineka Cipta: Jakarta.

Suyudi, Aria dkk, 2003, Analisis Kepailitan Indonesia (Kepailitan di Negeri Pailit), PSHK, Jakarta.

Yuhassarie, Emmy, 2005, Prosinding Rangkaian Lokakarya Terbatas MasalahMasalah Kepailitan dan Wawasan Hukum Bisnis Lainnya "UNDANGUNDANG KEPAILITAN DAN PERKEMBANGANNYA”, Pusat Pengkajian Hukum, Jakarta.

Kitab Undang-Undang Hukum Acara Perdata.

Undang-Undang Nomor 34 Tahun 2004 Tentang Kepailitan dan Penundaan Kewajiban Pembayaran Utang.

Khairandy, Ridwan, 2011, Landasan Filosofis Kekuatan Mengikatnya Kontrak, Jurnal Hukum, Fakultas Hukum Universitas Islam Indonesia, Yogyakarta. doi: http://jurnal.uii.ac.id/index.php/IUSTUM/article/view/7232. Akses 19 April 2017.

Noviana, Nina, 2006, Perubahan Pokok Dalam Peraturan Kepailitan Menurut Undang-Undang Nomor 37 Tahun 2004 Tentang Kepailitan Dan Penundaan Kewajiban Pembayaran Utang, Jurnal Hukum dan Pembangunan, Jakarta. doi: http://jhp.ui.ac.id/index.php/home/article/view/1427/1347. Akses 28 Oktober 2017.

Putriyanti, Erma Defiana dan Tata Wijayanta, 2010, Kajian Hukum Tentang Penerapan Pembuktian Sederhana Dalam Perkara Kepailitan, Mimbar Hukum, Jurnal Ilmiah Mahasiswa Universitas Gajah Mada, Yogyakarta. doi: https://jurnal.ugm.ac.id/jmh/article/view/16240/10786. Akses 28 Oktober 2017.

Wijayanta, Tata, 2014, Kajian Tentang Pengaturan Syarat Kepailitan Menurut Undang-Undang Nomor 37 Tahun 2004, Mimbar Hukum, Jurnal Ilmiah

B.I Checking Sebagai Alat Bukti Dalam Pembuktian Sederhana Perkara Kepailitan 
Mahasiswa Universitas Gajah Mada, Yogyakarta. doi: https://jurnal.ugm.ac.id/jmh/article/view/16063/10609. Akses 28 Oktober 2017.

Wijayanti, Indah, 2006, Penerapan Penafsiran Pembuktian Sederhana Dalam

Perkara Kepailitan, Jurnal Hukum Universitas Brawijaya, Malang, doi: http://hukum.studentjournal.ub.ac.id/index.php/hukum/article/view/1252/12 $\underline{08}$, Akses 28 Oktober 2017.

Adiyanto, Harry Baskoro, "Memperoleh Informasi Debitor Individual (IDI)

Historis (Pinjaman, Kredit, Hutang) di Bank Indonesia (online)", http://harribaskoro.com/memperoleh-informasi-debitur-individual-idi-dibank-indonesia/. Akses 28 Mei 2017.

Kadir, Yunita, 2014, "Pembuktian Sederhana Kepailitan”, Calypatra, Jurnal Ilmiah Mahasiswa Universitas Surabaya, Surabaya. Dipublikasikan.

Yulianny, Nenny, 2005, “Kajian Penyelesaian Perkara Utang Piutang Putusan Pengadilan Niaga dalam Hubungannya dengan Pengertian Sumir Berdasarkan Undang-Undang Nomor 4 Tahun 1998 tentang Kepailitan", Tesis, Program Pascasarjana Magister Kenotariatan Universitas Diponegoro, Semarang. Dipublikasikan

Putusan Mahkamah Agung No.748 K/PDT.SUS/2012.

Putusan Mahkamah Agung RI No.443 K/Pdt.Sus/2009.

Putusan No. 70/PAILIT/2010/PN.NIAGA.JKT.PST

Putusan No:1/PKPU/2012/PN.NIAGA.SMG.

Putusan No. 24//PDT.SUS/2014/PN.NIAGA.JKT.PST.

Putusan No. 86/Pdt.Sus-PKPU/2016/PN.Niaga.JKT.PST

Putusan No: 92/PDT.SUS/PKPU/2015/PN.NIAGA.JKT.PST

Putusan No: 93/PDT.SUS/PKPU/2015/PN.NIAGA.JKT.PST

B.I Checking Sebagai Alat Bukti Dalam Pembuktian Sederhana Perkara Kepailitan 